\begin{tabular}{|c|c|c|}
\hline & $\begin{array}{c}\text { Klinikal Sains } 9(1)(2021) \\
\text { JURNAL ANALIS KESEHATAN } \\
\text { KLINIKAL SAINS }\end{array}$ & KLINKALSAINS \\
\hline $\begin{array}{l}\text { UNIVERSITAS } \\
\text { ABDURRAB }\end{array}$ & http://jurnal.univrab.ac.id/index.php/klinikal & 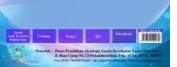 \\
\hline
\end{tabular}

\title{
PERBEDAAN KADAR KOLESTEROL TOTAL PADA PASIEN PUASA DAN TIDAK PUASA
}

\author{
Sinta Nur Ifaliza ${ }^{1}$, Asrori $^{2}$, Ardiya Garini ${ }^{3}$ \\ Program Studi DIII Analis Kesehatan Politeknik Kesehatan Palembang \\ Jl. Sukabangun 1 No.1159 Sukarami, Kota Palembang, Sumatera Selatan \\ Telp 081278554189 \\ Email : ifalizasintanur@gmail.com
}

\section{Info Artikel \\ SejarahArtikel: \\ Diterima April 2021 \\ Disetujui Juni 2021 \\ Dipublikasikan Juni 2021 \\ Keywords: \\ Kolesterol Total, puasa, Tidak puasa, arteri koroner , ateros klerosis}

\begin{abstract}
Abstrak
Kolesterol merupakan zat berlemak yang diproduksi oleh hati. Kolesterol dapat ditemukan di seluruh tubuh dan berperan penting terhdap fungsi tubuh sehari-hari. Pemeriksaan kolesterol adal;ah salah satu parameter untuk mengetahui penyakit jantung pemeriksaan Kolesterol dalam serum digunakan sebagai indictor penyakit arteri koroner dan ateros klerosis. Selama 24 jam sebelum pemeriksaan, sebaiknya pasien tidak melakukan aktivitas berat karena kelelahan dapat berpengaruh pada hasil pemeriksaan. Penelitian ini bertujuan untuk mengetahui perbedaan hasil pemeriksaan kadar kolesterol total pada pasien puasa dan tidak puasa. Jenis penelitian adalah penelitian analitik dengan rancangan one group pre and posttest design. Penelitian ini dilaksanakan pada bulan maret 2020. Populasi penelitian adalah seluruh mahasiswa tingkat I dan II Jurusan Analis Kesehatan Politeknik Kesehatan Palembang. Sampel berupa serum dari 30 responden yang diambil secara simple random sampling. Analisis data menggunakan paired t-test. Berdasarkan hasil uji t diperoleh nilai $p=0,134(p>0,05)$ artinya $p>\alpha$ yang berarti tidak ada perbedaan yang bermakna pada kadar kolesterol pasien puasa dan tidak puasa.
\end{abstract}

Kata Kunci : Kolesterol Total, puasa, Tidak puasa, arteri koroner, ateros klerosis

\begin{abstract}
Background: Cholesterol is a fatty substance produced by the liver. Cholesterol can be found throughout the body and plays an important role in daily body functions. Cholesterol tests carried out in the laboratory are one of the parameters to determine heart disease. Cholesterol serum levels is used as an indicator of coronary artery disease and atherosclerosis. Since the fatigue can affect the examination result, patients should not perfom heavy activities during 24 hours before the examination. Objective :to know the difference of total cholesterol level on fasting and non fasting patients. Method :it was an analytical research with one group pre and posttest design. This research was conducted in March 2020. The population were all the $1^{\text {st }}$ and $2^{\text {nd }}$ grade students of the Medical Laboratory Technology Department of Health Polytechnic of Palembang. Samples were taken by simple random sampling. Paired t-test was used as a statistic analysis. Pursuant to result $t$ test of data obtained by $p$ value $=0,134(p>0,05)$ means there is no significant difference of fasting cholesterol levels and non-fasting cholesterol levels.

Keywords : Total Cholesterol, fasting, non fasting, arteri koroner, ateros klerosis
\end{abstract}


Alamat korespondensi :

ISSN 2338-4921

Co-Author (Korespondensi) : Asrori,

Kampus SukabangunJalanSukabangun 1, Sukarami, Palembang.

E-mail: asrori123@poltekkespalembang.ac.id

\section{PENDAHULUAN}

Pelayanan kesehatan di laboratorium klinik merupakan salah satu bagian dari pelayanan kesehatan yang dibutuhkan untuk membantu menegakkan diagnosis dengan cara menetapkan penyebab penyakit, menunjang sistem, kewaspadaan dini, pemeliharaan kesehatan, monitoring pengobatan dan pencegahan timbulnya penyakit.. Dalam upaya peningkatan kualitas kesehatan masyarakat di laboratorium klinik perlu dilakukan secara berkesinambungan dan bermutu (Siregar dkk., 2018). Bebebarapa jenis pemeriksaan yang dilakukan dilaboratorium klinik sah satunya ialah pemeriksaan kolesterol, hal ini dapat dijadikan indicator prevalensi penyakit jantung. (Riskesdas, 2018).

Kolesterol merupakan zat yang mengandung lemak yang diproduksi oleh hati, zat ini ditemukan di seluruh tubuh dan berperan penting untuk melakukan aktifitas kehidupan tubuh sehari-hari. Hati merupakan salah satu organ yang membuat sebagian besar kolesterol dalam tubuh dan hanya sebagian kecil yang berasal dari makanan. Tubuh juga dapat menyeibnagkan kolesterol yang dibuat sendiri dihati dengan asupan kolesterol dari akanan. Semakin banyak makanan berkadar kolesterol tinggi yang kita makan maka semakin sedikit tubuh memproduksi kolesterol (Morrell, 2007).

Pemeriksaan Kolesterol dalam serum digunakan sebagai indikator penyakit arteri korener dan aterosklerosis. Kondisi hiperkolesterolemia menyebabkan penumpukan pada ateri sehingga menyebabkan ateros klerosis yang berakibat pada penyumbatan pembuluh darah. Pasien harus melakukan puasa selama 12 Jam sebelum melakukan pemeriksaan kolesterol total, (Nugraha \& Badrawi, 2018).

Penelitian ini bertujuan untuk mengetahui perbedaan hasil pemeriksaan kadar kolesterol total puasa dan tidak puasa. Untuk menjaga validitas hasil pemeriksaan kadar kolesterol darah sebaiknya pasien diharuskan puasa selama 10 sampai 12 jam sebelum diambil darahnya, karena dengan puasa konsentrasi kolesterol dalam keadaan normal atau dalam keadaan sebenarnya, selama ini petugas laboratorium dalam pemeriksaan kadar kolesterol darah, belum atau tidak ada ketegasan dalam memutuskan kepada pasien. Hal ini sejalan dengan yang dikatakan bebrapa dokter spesialis penyakit dalam dan penyakit jantung bahwa pasiesn diharuskan berpuasa. Tujuannya ialah agar tidak terjadi kesalahan pengukiuran akibat adnya pengaruh lemak yang baru dikonsumsi. Namun hal itu berbanding terbalik dengan peraturan meteri RI Nomor 43 tahun 2013 yang menyatakan bahawa pemeriksaan kadar 
kolesteron merupakan salah satu pemeriksaan yang tidak diwajibkan untuk berpuasa (Kementerian Kesehatan RI Peraturan Menteri Kesehatan Republik Indonesia Nomor 43 Tahun 2013).

\section{METODE}

Pada penelitian ini jenis penelitian yang digunakan adalah penelitian yang analitik dengan rancanagan one group pre and posttest design yang bertujuan untuk membedakan hasil pemeriksaan kadar kolesterol total pada pasien yang puasa dengan yang tidak puasa. Sampel penelitian adalah seluruh mahasiswa tingkat I dan II Prodi DIII Analis Kesehatan Poltekkes Palembang yang bersedia menjadi responden yang akan diambil sampelnya. Jumlah sampel yang digunakan ialah 30. Kriteria Inklusi meliputi : mahasiswa rtingkat 1 dan tingkat 2 analis kesehatan poltekkes Palembang, konsisi kesehatan Sehat, dalam hal ini responden tidak memiliki keluhan atau tanda-tanda penyakit atau kelainan. Bersedia megikuti penelitian sedangkan kriteria eksklusi meliputi : Minum obat-obat penurun kolesterol, Minum vitamin C dan E. Pemeriksaan kolesterol menggunakan Photometer BTS-350 dengan metode Cholesterol Oxidase - Peroxidase. Analisis data menggunakan ujit-dependent. 


\section{ProsedurKerja}

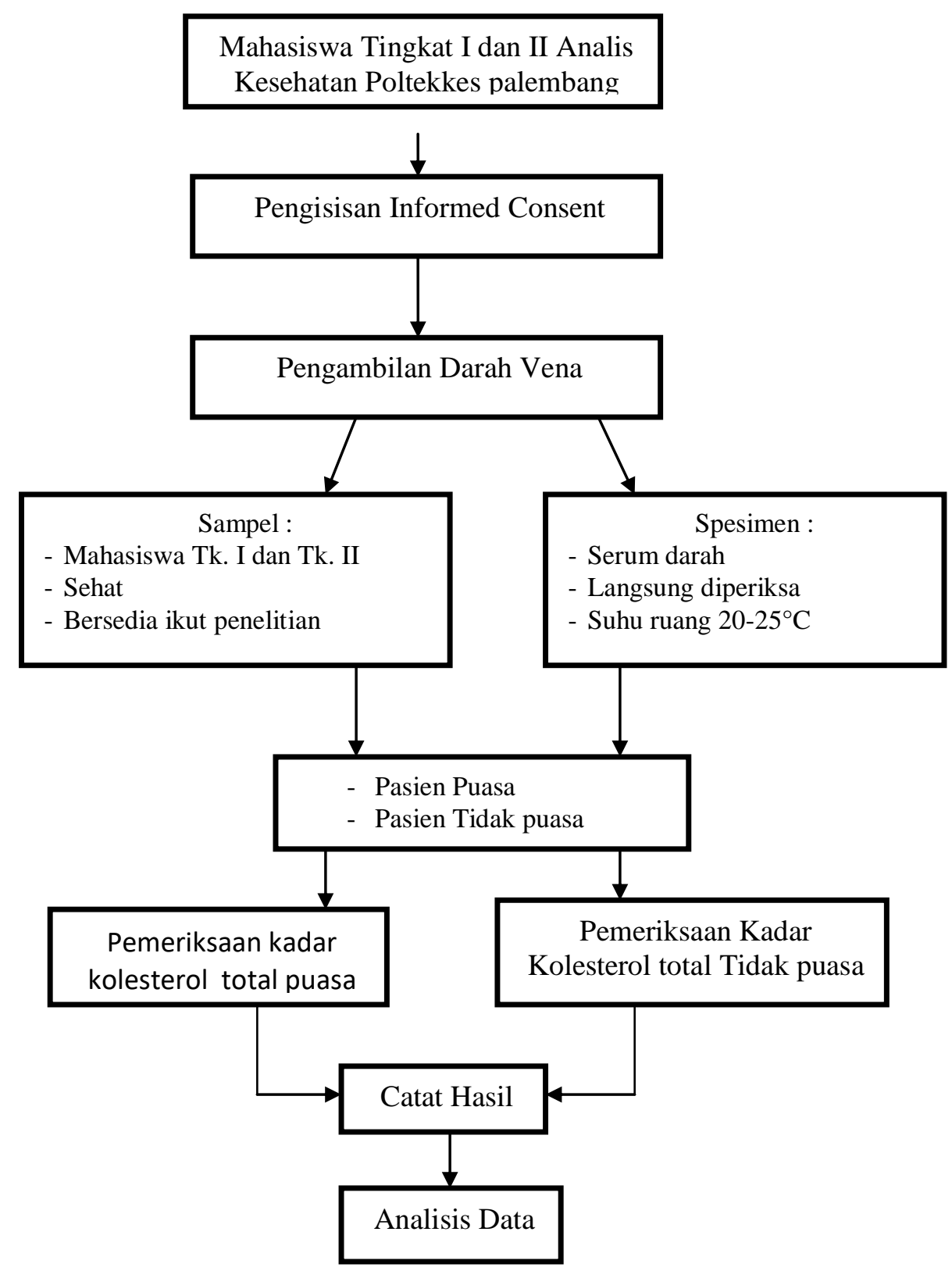

\section{HASIL DAN PEMBAHASAN}

\section{Kadar Kolesterol Pada Pasien Puasa}

berdasarkan analisis data yang telah dilakukan pada pasien kadar kolesterol total puasa diperoleh hasil sebagai berikut:

Tabel 1. Kadar Kolesterol Pada Pasien Puasa Pada mahasiswa Tingkat I dan II Jurusan Analis Kesehatan Poltekkes Kemenkes Palembang Tahun 2020

\begin{tabular}{ccccccc}
\hline \multicolumn{7}{c}{ Kadar Kolesterol Pada Pasien Puasa (mg/dL) } \\
\hline Variable & Mean & Median & SD & Min & Max & $95 \%$ CI \\
\hline Kolesterol Total & 177,8 & 177,5 & 27,7 & 110 & 231 & $167,4-188,2$ \\
\hline
\end{tabular}


Berdasarkan table diatas (Tabel 1) dapat diketahui bahwa rata-rata kadar kolesterol total pada pasien tidak puasa sebesar 177,8 mg/dL dari 30 Pasein, kecepatan pembentukan kolesterol dipengaruhi oleh konsentrasi kolesterol yang telah ada dalam tubuh. Apabila dalam tubuh terdapat kolsterol dalam jumlah cukup, maka kolesterol akan menghambat sendiri reasksi pembentukan (hambatan umpan balik), sebaliknya jika jumlah kolesterol sedikit karena berpuasa maka kecepatan pembentukan kolesterol akan meningkat (Wahono, 2006).

\section{Kadar kolesterol Pada Pasien Tidak Puasa Puasa}

Berdasarkan analisis data yang telah dilakukan pada kadar kolesterol pasien tidak puasa diperoleh hasil sebannagi berikut :

Tabel 2. Distribusi statistic kadar kolesterol total pada paisen tidak puasa Pada mahasiswa Tingkat I dan II Jurusan Analis Kesehatan Poltekkes Kemenkes Palembang Tahun 2020

\begin{tabular}{ccccccc}
\hline \multicolumn{7}{c}{ Kadar Kolesterol Total PasienTidakPuasa (mg/dL) } \\
\hline Variabel & Mean & Median & SD & Min & Max & $95 \%$ CI \\
\hline Kolesterol Total & 173,3 & 173 & 27,5 & 102 & 227 & $163-183,6$ \\
\hline
\end{tabular}

Berdasarkan tabel 2 terlihat bahwa kadar rata-rata kolsterol pada pasien tidak puasa sebesar 173,3 mg/dL daei 30 Pasien , Menurut Nordestgaard dkk. (2016), pada saat puasa kadar kolesterol total, LDL, dan Non - HDL sedikit mengalami penurunan yang disebabkan oleh asupan cairan, dan bukana supan makanan, dan karena itu jugaseperti air di izinkan untuk diminum saat puasa untuk pemeriksaan kolesterol. Menurut Langsted dkk. (2014) Kadar kolesterol total dan LDL berkurang hingga 3 hingga 4 jam setelah asupan makanan normal. Pengurangan ini adalah hemodilusi yang dihasilkan dari asupan cairan sehubungan dengan $\mathrm{m}$ akanan.

\section{Perbedaan Kadar Kolesterol Total Pada Pasien Puasa dan Tidak Puasa}

Berdasarkan analisis data menggunakan uji $\mathrm{T}$ dependent atau uji paired sampel test didapatkan hasil sebagai berikut:

Tabel 3. Perbedaan hasil pemeriksaan kadar kolesterol total pada pasien puasa dan tidak puasa

\begin{tabular}{ccccccc}
\hline & \multicolumn{6}{c}{ Kadar Kolesterol Total (mg/dL) } \\
\hline Variabel & $\mathrm{N}$ & Mean & Min & Max & Std. Deviasi & P value \\
\hline $\begin{array}{c}\text { Kolesterol Total } \\
\text { (Puasa) }\end{array}$ & 30 & 177,8 & 110 & 231 & 27,5 & \\
\hline $\begin{array}{c}\text { Kolesterol Total } \\
\text { (TidakPuasa) }\end{array}$ & 30 & 173,3 & 102 & 227 & 27,7 & 0,134 \\
\hline
\end{tabular}


Berdasarkan tabel 3 terlihat bahwa, tidak ada perbedaan kadar kolesterol total pada pasien puasa dan tidak puasa puasa. Menurut Eur Heart J (2016) menyatakan bahwa variasi konsentrasi kolesterol puasa dan non-puasa yang diukur pada individu yang sama pada dua kesempatan berbeda adalah serupa.

Hasil analisis data uji statistik diperoleh nilai $\mathrm{p}=0,134$ yang lebih besar dari alpha $(\alpha)$ 0,05 yang menunjukkan tidak adanya perbedaan . Menurut Nordestgaard dkk. (2016) menyatakan bahwa variasi konsentrasi kolesterol puasa dan tidak puasa yang diukur pada individu yang sama pada dua kesempatan berbeda adalah serupa. Menurut Langsted dkk. (2014), kadar lipid, lipoprotein dan polipoprotein setelah asupan makanan normal berbeda hanya sedikit dari tingkat dalam keadaan puasa, mungkin karena kebanyakan orang mengkonsumsi jauh lebih sedikit lemak pada makanan biasa dari pada selama testoleransi lemak

Hasil yang diperoleh dari penelitian menyatakan bahwa distribusi statistic responden dengan rata-rata nilai kadar kolesterol pada pasien puasa ialah $177,8 \mathrm{mg} / \mathrm{dL}$ sedangkan pada pasien yang tidak puasa diperoleh nilai rata-rata sebeasar $173,5 \mathrm{mg} / \mathrm{dL}$. Hasil ini sejalan dengan peraturan meteri RI Nomor 43 tahun 2013 yang menyatakan bahawa pemeriksaan kadar kolesterol merupakan salah satu pemeriksaan yang tidak diwajibkan untuk berpuasa. Hasil ini juga sejalan dengan penelitian Puspitasari (2017) tentangb perbedaan kadar kolestereol (LDL) pasien puasa dan tidak puasa dengan jenis penelitian analitik dengan rancangan cross sectional didapatkan hasil tidak ada perbedaan yang bermakna.

Penelitian ini berbeda debngan hasil penelitian yang telah dilakukan oleh Wahono (2006). yang menunjukkan bahwa ada perbeda anantara keadaan puasa dengan tidak puasa pada penetapan kadar kolesterol darah.Hal ini disebabkan adanya perbedaan perlakuan yaitu adanya variabel terkait atau faktor-faktor risiko.Wahono menggunakan variabel terkaitnya adalah merokok, umur, pendidikan dan agama, sedangkan peneliti hanya kadar kolesterol puasa dan tidak puasa.

\section{KESIMPULAN}

Berdasarkan analisa data tersebut diatas dapat disimpulkan bahwa tidak terjadi perbedaan yang siginfikan terhadap hasil pemeriksaan kadar kolsterol pasien puasa dan tidak puasa.

\section{UCAPAN TERIMAKASIH}

Ucapan terimakasih kepada pihak poltekkes Palembang dan seluruh civitas akademika yang telah berperan serta dan bekerjasaama dalam penelitian ini. 


\section{DAFTAR PUSTAKA}

Langsted, A., Kamstrup, P. R., \& Nordestgaard, B. G. (2014). Lipoprotein (A): Fasting And Nonfasting Levels, Inflammation, And Cardiovascular Risk. Atherosclerosis, 234(1), 95-101.

Morrell, J. (2007). Simple Guide: Kolesterol: Erlangga.

Nordestgaard, B. G., Langsted, A., Mora, S., Kolovou, G., Baum, H., Bruckert, E., . . Borén, J. (2016). Fasting Is Not Routinely Required For Determination Of A Lipid Profile: Clinical And Laboratory Implications Including Flagging At Desirable Concentration Cut-Points-A Joint Consensus Statement From The European Atherosclerosis Society And European Federation Of Clinical Chemistry And Laboratory Medicine. European Heart Journal, 37(25), 1944-1958.

Nugraha, G., \& Badrawi, I. (2018). Pedoman Teknik Pemeriksaan Laboratorium Klinik Untuk Mahasiswa Teknologi Laboratorium Medik. Jakarta: Trans Info Media.

Puspitasari, R. M. (2017). Perbedaan Kadar Kolesterol Ldl Pasien Puasa Dan Tanpa Puasa Di Rsud Salatiga. Universitas Muhammadiyah Semarang.

Riskesdas, R. (2018). Laporan Nasional Riskesdas Tahun 2018: Jakarta.

Siregar, M. T., Wulan, S. W., Setiawan, D., \& Nuryati, A. (2018). Kendali Mutu.

Speicher, C. E., \& Smith Jr, J. W. (1996). Pemilihan Uji Laboratorium Yang Efektif: Choosing Effective Laboratory Tests.

Wahono, D. P. B. (2006). Perbedaan Kadar Kolesterol Darah Antara Keadaan Puasa Dengan Tidak Puasa. Universitas Airlangga. 